\title{
FAKTOR-FAKTOR YANG MEMPENGARUHI KEJADIAN LASERASI PERINEUM DI KABUPATEN TEGAL
}

\section{THE INFLUENCING FACTORS OF PERINEUM LASERATION IN TEGAL REGENCY}

\author{
Yuni Fitriani $^{1}{ }^{\bowtie}$,Tri Agustina Hadiningsih ${ }^{2}$,lka Esti Anggraeni ${ }^{3}$ \\ Universitas Bhamada Slawi, Jl. Cut Nyak Dien, Kalisapu, Slawi, Kab. Tegal, Indonesia \\ Correspondence Email: yuninayla05@gmail.com
}

\begin{abstract}
ABSTRAK
Kematian ibu di Provinsi Jawa Tengah tahun 2019 mengalami penurunan dibandingkan tahun 2018, dengan AKI tahun 2019 sebesar 76,93/100.000 kelahiran hidup sebanyak 416 kasus. Laserasi perineum merupakan salah satu penyebab perdarahan postpartum. Berdasarkan data yang diperoleh dari Puskesmas Margasari terdapat sebanyak 232 (30\%) dari total persalinan 775 kasus laserasi perineum selama tahun 2019. Tujuan penelitian ini adalah untuk mengetahui faktorfaktor yang mempengaruhi kejadian laserasi perineum di Puskesmas Margasari. Jenis penelitian ini adalah penelitian kuantitatif yaitu deskriptif analitik dengan desain penelitian retrospektif untuk melihat faktor-faktor yang mempengaruhi kejadian laserasi perineum di Puskesmas Margasari. Penelitian ini dilakukan menggunakan data pesalinan tahun 2020 jumlah sampel 350 orang (30\%) dari total populasi. Dengan mengunakan Uji regresi logistik. Hasil penelitian menunjukkan ada hubungan antara usia ibu hamil $(p=0,000)$, paritas ibu $(p=0,000)$, berat badan bayi $(p=0,000)$ dengan kejadian laserasi perineum.
\end{abstract}

Kata kunci: laserasi; perineum; persalinan

\section{ABSTRACT}

Maternal mortality in Central Java Province in 2019 decreased compared to 2018, it was 76.93/100,000 live births with 416 cases in 2019. Perineum Laceration is one of the causes of postpartum hemorrhage. Based on data obtained from the Margasari District Health Center, there were 232 (30\%) of the total 775 cases of perineum laceration delivered in 2019. The purpose of this study was to determine the factors that influence the incidence of Perineum Laceration at the Margasari Health Center. This type of research was a quantitative research that is descriptive analytic with a retrospective research design to see the factors that influence the incidence of Perineum Laceration at Margasari Health Center. This study was conducted using labor data in 2020 with a sample of 350 people (30\%) of the total population by using logistic regression test. The results showed that there was a relationship between the age of pregnant women $(p=0.000)$, maternal parity $(p=0.000)$, infant weight $(p=0.000)$ and the incidence of perineum laceration.

Keywords: laceration; perineum; labor

Keywords: laseration; perineum; childbirth

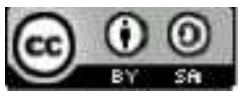

Jurnal SMART Kebidanan is licensed under a Creative Commons Attribution-ShareAlike 4.0 International License 


\section{PENDAHULUAN}

Perdarahan postpartum merupakan penyebab utama AKI di Kabupaten Tegal (Dinas Kesehatan Kabupaten Tegal, 2019). Laserasi perineum merupakan salah satu penyebab dari perdarahan postpartum. Laserasi perineum memberikan perdarahan dalam jumlah yang bervariasi benyaknya. Sumber perdarahan dapat berasal dari perineum, serviks, dan robekan uterus (rupture uteri)(Bobak, 2012).

Berdasarkan data yang diperoleh dari Puskesmas Margasari terdapat sebanyak 232 (30\%) dari total persalinan 775 , kasus laserasi perineum di tahun 2019 (data Puskesmas Margasari Kabupaten Tegal, 2019). Persalinan adalah proses pengeluaran hasil konsepsi yang dapat hidup dari dalam uterus ke dunia luar (Jannah, 2015). Laserasi perineum umumnya terjadi pada garis tengah dan bisa menjadi luas apabila kepala janin lahir terlalu cepat (Wiknjosastro, 2017).

Laserasi perineum adalah laserasi pada ruang berbentuk jajaran genjang yang terletak dibawah dasar panggul yang terjadi secara alami tanpa tindakan pada saat persalinan. Laserasi perineum dapat terjadi karena perineum kaku, persalinan presipitatus, pimpinan persalinan yang salah, tidak terjalinnya kerjasama yang baik dengan ibu selama proses persalinan, paritas, berat bayi baru lahir dan persalinan dengan tindakan vakum atau forcep (Kuswanti, 2014).

Derajat laserasi perineum antara lain derajat pertama, yaitu laserasi mengenai mukosa dankulit perineum, tidak perlu dijahit; derajat kedua, yaitu laserasi mengenai mukosa vagina, kulit danjaringan perineum (perlu dijahit); derajat ketiga, yaitu laserasi mengenai mukosa vagina, kulit, jaringan perineum dan spingter ani; derajat empat, yaitu laserasi mengenai mukosa vagina, kulit,jaringan perineum dan spingter ani yang meluas hingga ke rectum rujuk segera (Varney, 2010). Faktor-faktor yang mempengaruhi laserasi perineum antara lain faktor ibu (usia, paritas,jarak kelahiran dan cara meneran), faktor janin (berat badan lahir bayi, presentasi, hydrocephalus dan distosia bahu), faktor persalinan (vacum ekstraksi, embriotomi dan partus precipitatus) dan faktor penolong persalinan (Varney, 2010).

Macam-macam laserasi perineum yang dapat mengakibatkan perdarahan sesuai derajat laserasi yang terjadi: pada laserasi perineum derajat I dan II jarang terjadi perdarahan, namun pada laserasi perineum derajat III dan IV sering menyebabkan perdarahan postpartum (Bobak, 2012). Berat bayi lahir merupakan salah satu faktor resiko yang meningkatkan kejadian perlukaan perineum selama kelahiran. Semakin besar bayi yang dilahirkan meningkatkan resiko terjadinya laserasi perineum (Sekartini, 2013).

Dari pencapaian data di Pukesmas Margasari Kabupaten Tegal Tahun 2019 didapatkan dari 750 ibu bersalin, terdapat 232 (30\%) ibu melahirkan dengan laserasi perineum (data Puskesmas Margasari, 2019). Tingginya kejadian laserasi perineum di Puskesmas Margasari dan besarnya dampak yang diakibatkan karena laserasi perineum membuat peneliti tertarik untuk melakukan penelitian yang berjudul "Faktor-Faktor yang mempengaruhi kejadian laserasi perineum di Puskesmas Margasari".

\section{METODE}

Jenis penelitian ini adalah penelitian kuantitatif yang bersifat deskriptif analitik dengan rancangan penelitian retrospektif untuk faktor-faktor yang mempengaruhi laserasi perineum. Populasi penelitian ini adalah seluruh ibu yang melahirkan di Puskesmas Margasari Kabupaten. Tegal pada tahun 2020. Sedangkan sampel dalam penelitian ini adalah 350 (30\%) dari total populasi. Variabel dalam penelitian terdiri dari variabel Bebas yaitu usia ibu, berat badan bayi dan paritas dan variabel terikat yaitu kejadian laserasi perineum. Pengambilan data menggunakan data sekunder yaitu rekam medis. Uji analisis data menggunakan Uji regresi logistik.

\section{HASIL}

Hasil penelitian membahas tentang karakteristik data umum dan data khusus penelitian, serta hasil tabulasi silang antara variabel bebas dan variabel terikat. Karakteristik responden berdasarkan usia ibu hampir seluruhnya $(75,7 \%)$ 
dari responden yaitu 265 responden berusia 20 35 tahun. Sedangkan, paling sedikit usia ibu $(6,3 \%)$ dari responden yaitu 22 responden berusia kurang dari 20 tahun. karakteristik responden berdasarkan paritas ibu hampir seluruhnya (54,9\%) dari responden yaitu 192 responden masuk dalam kategori multipara. Sedangkan, paling sedikit paritas ibu $(0,3 \%)$ dari responden yaitu 1 responden masuk dalam kategori grande multipara. karakteristik responden berdasarkan berat badan bayi hampir seluruhnya $(90,9 \%)$ dari responden yaitu 318 responden masuk dalam kategori berat badan bayi 2500-4000 gram. Sedangkan, paling sedikit berat badan bayi $(4,3 \%)$ dari responden yaitu 15 responden masuk dalam kategori > 4000 gram. Karakteristik responden berdasarkan laserasi hampir seluruhnya $(50,9 \%)$ dari responden yaitu 178 responden mengalami laserasi.

Penjelasan temuan tersebut menjelaskan bahwan masih banyaknya kejadian leserasi perineum pada ibu hamil usia 20-35 tahun dengan paritas ibu multipara pada berat badan bayi antara 2500-4000 gram.

Tabel 1. Data Karakteristik Responden

\begin{tabular}{clccc}
\hline No & Variabel & Kategori & Frekuensi $(\mathbf{n})$ & Presentase (\%) \\
\hline 1 & Usia ibu & $<20$ tahun & 22 & 6,3 \\
& & $20-35$ tahun & 265 & 75,7 \\
& & $>35$ tahun & 63 & 18,0 \\
\hline 2 & \multirow{2}{*}{ Paritas ibu } & Primipara & 157 & 44,8 \\
& & Multipara & 192 & 54,9 \\
& & Grandemultipara & 1 & 0,3 \\
\hline \multirow{2}{*}{3} & Berat badan & $<2500$ gram & 17 & 4,8 \\
& bayi & 2500-4000 gram & 318 & 90,9 \\
& & $>4000$ gram & 15 & 4,3 \\
\hline 4 & Laserasi & Ya & 178 & 50,9 \\
& perineum & Tidak & 172 & 49,1
\end{tabular}

Temuan berdasarkan usia responden yang mengalami laserasi perineum sebanyak 20-35 tahun yaitu 116 responden (33,1\%), sedangkan paling sedikit adalah responden yang berusia < 20 tahun dan tidak mengalami laserasi perineum yaitu 7 responden (2,0\%). Paling banyak responden masuk dalam kategori multipara dan mengalami laserasi perineum yaitu 115 responden (32,9\%), sedangkan tidak ada responden yang masuk dalam kategori grandemultipara dan tidak mengalami laserasi perineum yaitu 0 responden (0\%).Paling banyak responden memiliki berat badan bayi 2500-4000 gram mengalami laserasi perineum yaitu 163 responden $(46,6 \%)$, sedangkan tidak ada responden yang memiliki berat badan bayi kurang dari 2500 gram dan mengalami laserasi perineum yaitu 0 responden (0\%). (Tabel 2)

Tabel 2. Tabulasi silang hubungan antar faktor yang berhubungan dengan kejadian laserasi perineum tahun 2020

\begin{tabular}{|c|c|c|c|c|c|c|}
\hline \multirow{3}{*}{ Variabel } & \multirow{3}{*}{ Kategori } & \multicolumn{4}{|c|}{ Laserasi Perineum } & \multirow{3}{*}{$P$} \\
\hline & & \multicolumn{2}{|r|}{$\mathrm{Ya}$} & \multicolumn{2}{|c|}{ Tidak } & \\
\hline & & $\mathrm{n}$ & $(\%)$ & $\mathrm{N}$ & $(\%)$ & \\
\hline \multirow[t]{3}{*}{ Usia ibu hamil } & $<20$ tahun & 15 & 4.3 & 7 & 2.0 & 0.000 \\
\hline & 20 - 35 tahun & 116 & 33.1 & 149 & 42.6 & \\
\hline & $>35$ tahun & 47 & 13.4 & 16 & 4.6 & \\
\hline \multirow[t]{3}{*}{ Paritas ibu } & Primipara & 62 & 17.7 & 95 & 27.1 & 0.000 \\
\hline & Multipara & 115 & 32.9 & 77 & 22.0 & \\
\hline & Grandemultipara & 1 & 0.3 & 0 & 0 & \\
\hline \multirow[t]{3}{*}{ Berat badan bayi } & $<2500$ gram & 0 & 0 & 17 & 4.8 & 0.000 \\
\hline & $2500-4000$ gram & 163 & 46.6 & 155 & 44.3 & \\
\hline & $>4000$ gram & 15 & 4.3 & 0 & 0 & \\
\hline
\end{tabular}


Hasil analisis regresi logistik mendapatkan nilai $p=0.876$ untuk variable umur ibu, nilai $p=0.466$ untuk variable paritas dan nilai $p=0.000$ untuk variable berat badan bayi. Hal ini menunjukkan bahwa berdasarkan analisis multivariat ada hubungan berat badan bayi dengan kejadian laserasi perineum di Puskesmas Margasari Kabupaten Tegal Tahun 2020. Namun, tidak ada hubungan umur dan paritas dengan kejadian laserasi perineum di Puskesmas Margasari Kabupaten Tegal Tahun 2020.

Hasil multivariat juga menunjukkan meskipun nilai $p$ tidak signifikan, namun umur resiko rendah (20-35 tahun) dapat menurunkan kejadian laserasi perinium sebesar 0.13 kali. Paritas (multipara) juga menurunkan kejadian laserasi perineum sebesar 0.76 kali Berat badan bayi kurang dari 2500 juga menurunkan kejadian laserasi perineum sebesar 21.13 kali.

Nilai nagelkerke $r$ square menunjukkan nilai 0.204, hal ini menunjukkan bahwa variabel yang diteliti dalam penelitian menunjukkan faktor-faktor yang diteliti dalam penelitian berhubungan dengan kejadian laserasi perineum sebesar $20.4 \%$. Sedangkan sisanya $79.6 \%$, hubungan dengan kejadian laserasi perineum dapat dipengaruhi variabel di luar penelitian ini.

Tabel 3. Analisis Multivariat Faktor yang

Berhubungan dengan Kejadian Laserasi

Perineum di Puskesmas Margasari Kabupaten Tegal Tahun 2020

\begin{tabular}{lcccc}
\hline \multirow{2}{*}{$\begin{array}{l}\text { Variabel } \\
\text { Independen }\end{array}$} & \multirow{B}{*}{\begin{tabular}{c} 
Cl (95\%) \\
\cline { 3 - 5 }
\end{tabular}} & $\begin{array}{c}\text { Batas } \\
\text { Bawah }\end{array}$ & $\begin{array}{c}\text { Batas } \\
\text { Atas }\end{array}$ \\
\hline Umur & -0.132 & 0.519 & 1.481 & 0.876 \\
Paritas & -0.765 & 0.282 & 0.769 & 0.466 \\
Berat badan & - & 0.000 & 0.000 & 0.000 \\
bayi & 21.139 & & & \\
Nagelkerke R Square : 0.204 & & \\
\hline
\end{tabular}

\section{PEMBAHASAN}

Hubungan Usia dengan Kejadian Laserasi Perineum

Berdasarkan hasil penelitian dari 350 responden di Puskesmas Margasari paling banyak responden berusia 20-35 tahun dan mengalami laserasi perineum yaitu 116 responden $(33,1 \%)$, sedangkan paling sedikit adalah responden yang berusia $<20$ tahun dan tidak mengalami laserasi perineum yaitu 7 responden (2,0\%).Berdasarkan hasil perhitungan menggunakan rumus uji chi square menunjukkan nilai $p$-value sebesar $0,000<\alpha(0,05)$, karena nilai $p$-value $<0,05$ maka $\mathrm{H}_{\mathrm{o}}$ ditolak.

Usia perempuan paling tepat untuk hamil dan melahirkan adalah 20-35 tahun.Pada usia muda ( $<20$ tahun) dari segi biologis perkembangan alat-alat reproduksinya belum sepenuhnya optimal. Elastisitas otot-otot panggul dan sekitarnya serta alat-alat reproduksi pada umumnya mengalami kemunduran akan mengalami kemunduran pada usia lebih dari 35 tahun, juga besar kemungkinan akan mengalami kelelahan sehingga resiko kehamilan dan kelahiran lebih tinggi. Sedangkan pada usia < 20 tahun, organ-organ reproduksi belum berfungsi secara sempurna, sehingga apabila terjadi kehamilan dan persalinan akan lebih mudah mengalami komplikasi. Selain itu, kekuatan otot- otot perineum dan otot-otot perut belum bekerja secara optimal, sehingga sering terjadi persalinan lama atau macet yang memerlukan tindakan. Faktor resiko untuk persalinan sulit pada ibu yang belum pernah melahirkan pada kelompok umur ibu dibawah 20 tahun dan pada kelompok umur di atas 35 tahun adalah 3 kali lebih tinggi dari kelompok umur reproduksi sehat (20-35 tahun) (Frigerio et al, 2018).

Menurut Mochtar (2012) meskipun umur ibu normal pada saat kehamilan dan persalinan yaitu umur 20-35 tahun dapat terjadi robekan perineum apabila ibu tidak berolahraga dan rajin bersenggama. Kelenturan jalan lahir dapat berkurang apabila calon ibu kurang berolahraga atau genetalianya sering terkena infeksi. Infeksi akan mempengaruhi jaringan ikat dan otot dibagian bawah dan membuat kelenturannya hilang (karena infeksi membuat jalan lahir menjadi kaku). Hal ini juga dipengaruhi oleh perineum yang sempit dan elastisitas perineum sehingga 
akan mudah terjadinya robekan jalan lahir, oleh karena itu bayi yang mempunyai lingkar kepala maksimal tidak dapat melewatinya sehingga dapat menyebabkan rupture perineum.

Penelitian ini sejalan dengan hasil penelitian Absari, 2017 dimana dari 41 responden $80,5 \%$ ibu termasuk dalam kategori usia risiko rendah yang mengalami laserasi perineum.

Laserasi perineum selalu menimbulkan perdarahan dalam jumlah yang bervariasi. Perdarahan yang berasal dari jalan lahir harus dievaluasi, yaitu sumber dan jumlah perdarahan sehingga dapat segera ditangani. Robekan yang terjadi bisa ringan (lecet, laserasi), luka episiotomi, robekan perineum spontan derajat ringan sampai ruptur perineum totalis (sfingter ani terputus), robekan pada dinding vagina, forniks uteri, serviks, daerah sekitar klitoris dan uretra dan bahkan yang terberat rupture uteri (Nurjannah, 2015).

Hasil penelitian menunjukkan bahwa ada hubungan usia dengan kejadian laserasi perineum di Puskesmas Margasari. Oleh karena itu penting bagi tenaga kesehatan untuk memberikan informasi ataupun mengadakan kelas ibu hamil dalam pemberian komunikasi, informasi dan edukasi terkait informasi yang berhubungan dengan kehamilan khususnya pencegahan risiko perdarahan akibat laserasi perineum pada proses persalinan.

\section{Hubungan Paritas dengan Kejadian Laserasi Perineum}

Berdasarkan hasil penelitian dari 350 responden di Puskesmas Margasari paling banyak responden masuk dalam kategori multipara dan mengalami laserasi perineum yaitu 115 responden (32,9\%), sedangkan tidak ada responden yang masuk dalam kategori grandemultipara dan tidak mengalami laserasi perineum yaitu 0 responden (0\%). Hasil perhitungan menggunakan rumus uji chi sqaure menunjukkan nilai $p$-value sebesar $0,000<\alpha(0,05)$, karena nilai $p$-value $<0,05$ maka $\mathrm{H}_{\mathrm{o}}$ ditolak.
Hasil penelitian ini sejalan dengan penelitian terdahulu yang dilakukan oleh Nurjanah, 2015 dimana ada hubungan paritas ibu bersalin dengan kejadian ruptur perineum pada persalinan normal.

Multipara adalah wanita yang telah melahirkan anak lebih dari satu kali atau 2 anak atau lebih. Menurut teori Saifuddin (2012), rupture perineum terjadi baik pada primipara maupun multipara karena samasama mempunyai resiko, tergantung bagaimana penolong melakukan penanganan pada saat proses persalinan serta keadaan ibu sebelum bersalin baik kondisi fisik maupun kesiapan psikologis. Penyebab rupture perineum pada primipara karena kelenturan jalan lahir atau elastisitas perineum, mengejan yang tergesa-gesa dan tidak teratur, serta berat badan bayi baru lahir. Sedangkan penyebab rupture perineum pada multipara sebagian karena berat badan bayi baru lahir, kerapuhan perineum, asuhan sayang ibu yang kurang baik sehingga proses persalinan kurang terkendali seperti ibu kelelahan, mengejan sebelum waktunya sehingga partus menjadi macet atau lambat (saifuddin, 2012)

Laserasi perineum terjadi pada semua persalinan pertama dan tidak jarang juga pada persalinan berikutnya. Kejadian laserasi ini dapat dihindarkan atau dikurangi dengan menjaga dasar panggul tidak dilalui oleh kepala janin dengan cepat, sebaliknya kepala janin yang akan lahir jangan ditahan terlalu kuat dan lama, karena akan menyebabkan asfiksia dan pendarahan dalam tengkorok janin, dan melemahkan otot-otot dan fasia pada dasar panggul karena diregangkan terlalu lama (Endozien, 2014).

Hasil penelitian menunjukkan bahwa ada hubungan paritas dengan kejadian laserasi perineum di Puskesmas Margasari. Dampak dari ruptur perineum ini dapat menyebabkan trauma bagi seorang ibu terutama berpengaruh pada kesiapan persalinan berikutnya, sehingga sudah seharusnya deteksi dini terhadap kejadian ruptur perineum dilakukan sejak masa kehamilan dengan cara melaksanakan kelas 
ibu hamil, melakukan antenatal care yang berkualitas, saat proses persalinan dengan cara memberikan asuhan sayang ibu dan masa post partum mulai dari saat pemulihan sampai persiapan bagi kehamilan selanjutnya.

\section{Hubungan Berat Badan Bayi dengan Kejadian Laserasi Perineum}

Berdasarkan hasil penelitian dari 350 responden di Puskesmas Margasari paling banyak responden memiliki berat badan bayi 2500-4000 gram mengalami laserasi perineum yaitu 163 responden (46,6\%), sedangkan tidak ada responden yang memiliki berat badan bayi kurang dari 2500 gram dan mengalami laserasi perineum yaitu 0 responden (0\%). Hasil perhitungan menunjukkan nilai $p$-value sebesar $0,000<\alpha(0,05)$, karena nilai $p$-value $<0,05$ maka Ho ditolak.

Penelitian diatas sejalan dengan penelitian yang dilakukan oleh Yuliana (2012) di rumah bersalin Sally Kec.Medan Tembung tahun 2012 dengan kesimpulan bahwa mayoritas kejadian ruptur perineum berdasarkan berat badan lahir dari 78 kasus di peroleh pada berat badan 2500-4000 gram sebanyak 47 kasus $(97,9 \%)$

Pusposari (2010), menyatakan bahwa berat badan bayi lahir 2500- 4000 gram dapat menyebabkan ruptur perineum apabila dipengaruhi ibu yang mengejan terlalu kuat saat melahirkan kepala janin dan adanya cara mengejan yang kurang baik, menimbulkan kerusakan pada jaringan jalan lahir dan hal ini bisa menyebabkan terjadinya robekan pada perineum. His yang adekuat dapat membuka jalan lahir dengan cepat, artinya jika hisnya adekuat tetapi ibu menerannya tidak kuat maka akan terjadi pembukaan jalan lahir. Sedangkan jika ibu mengejan terlalu kuat saat melahirkan kepala bayi yang merupakan diameter terbesar janin maka akan menyebabkan laserasi perineum

\section{KESIMPULAN}

Berdasarkan hasil perhitungan menggunakan rumus uji chi squaremenunjukkan nilai $p$-value sebesar $0,000<\alpha(0,05)$, karena nilai $p$-value $<0,05$ maka Ho ditolak. Hal ini menunjukkan bahwa ada hubungan usia $(\mathrm{p}=0.000)$, paritas $(p=0.000)$ dan berat badan bayi $(p=0.000)$ dengan kejadian laserasi perineum di Puskesmas Margasari Kabupaten Tegal Tahun 2020. Indikator capaian dalam penelitian ini adalah mengetahui faktor-faktor yang mempengaruhi kejadian laserasi perineum. Agar dapat dilakukan tindak lanjut sebagai upayapenurunan angka kematian ibu dan bayi.

\section{REFERENSI}

Abrasi, Yuni (2017) Faktor-Faktor Yang Mempengaruhi Kejadian Rupture Perineum Pada Persalinan Normal Di Bpm Wayan Witri Sleman Yogyakarta

Bobak, Lowdermilk, Jense. 2012. Buku Ajar Keperawatan Maternitas. Jakarta: EGC

Dinas Kesehatan Kabupaten Tegal, (2019). Profil Dinas Kesehatan Kabupaten Tegal

Dinas Kesehatan Kabupaten Tegal, (2020). Profil Dinas Kesehatan Kabupaten Tegal

Edozien, L. C., Gurol-Urganci, I., Cromwell, D. A., Adams, E. J., Richmond, D. H., Mahmood, T. A., \& Meulen, J. H. van der. (2014). Impact of third- and fourth-degree perineal tears at first birth on subsequent pregnancy outcomes: a cohort study. BJOG: An International Journal of Obstetrics \& Gynaecology, 121(13), 1695-1703. https://doi.org/10.1111/14710528.12886

Frigerio, M., Manodoro, S., Bernasconi, D. P., Verri, D., Milani, R., \& Vergani, P. (2018). Incidence and risk factors of third- and fourth-degree perineal tears in a single Italian scenario. Europian Journal of Obstetrics and Gynecology and Reproductive Biology, 221, 139143.

https://doi.org/https://doi.org/10.1016/j. ejogrb.2017.12.042

Kuswanti, Ina.S. Si. T, M. Kes. 2014. Asuhan kehamilan. Yogyakarta : PT. Pustaka Pelajar 
Mochtar, R. (2012). Sinopsis Obstetri Fisiologi Patologi. Edisi III. Jakarta : ECG

Nurjanah, N. (2015). Persalinan Normal di RSUD Indramayu Periode Januari Juni Tahun 2015. 10, 221-232.

Pusposari, D. M . (2010). Theses. Hubungan Berat Badan Janin Dengan Terjadinya Laserasi Perineum Pada Proses Persalinan (Studi Di Puskesmas Srondol

Saiffudin, Abdul Bari, (2012). Pelayanan Kesehatan Maternal dan Neonatal. Jakarta; Bina Pustaka
Sekartini R, Tikoalu J. Air Susu lbu dan Tumbuh Kembang Anak. Ikatan Dokter Anak Indonesia. 2013. Diunduh dari: http://www.idai.or.id/artikel//klinik/asi/airsusu-ibu-dan-tumbuh-kembanganak

Varney, Helen. 2010. Buku Ajar Asuhan Kebidanan Edisi 4. Jakarta. EGC

Wiknjosastro, Hanifa. (2017). IImu Kebidanan. Cetakan ke-5. Jakarta: Yayasan Bina Pustaka Sarwono Prawiroharjo.

Yuliana. (2012). Faktor-faktor yang Mempengaruhi Rupture Perineum Di Rumah Bersalin Sally Kecamatan Medan Tembung tahun 2012. 